\title{
A TÁRSADALOMFÖLDRAJZ ÉS A REGIONÁLIS TUDOMÁNY KÜLÖNBSÉGEIRŐL ${ }^{1}$
}

\section{DUSEK TAMÁS}

Probáld Ferenc a társadalomföldrajz és a regionális tudomány különbségeit számba véve (a Tér és Társadalom 2007/1. számában) arra a következtetésre jut, hogy a „tárgykör lényegi egyezését árnyaló szemléleti és módszertani eltérések összességükben sincsenek olyan nagyok, hogy elvont tudományrendszertani szempontból indokolttá vagy épp szükségszerūvé tették volna egy különálló diszciplina [a regionális tudomány] kialakulását." İásomban a tanulmány ezen állításával kívánok foglalkozni, annál is inkább, mert könyvemben - később ismertetendő eltérő okokból - hasonló végkövetkeztetésre jutottam az isardi regional science kapcsán: „A regional science számára az ismeretek felesleges megkettőződése reálisabb veszély, mint a módszertudományként felfogott regionális tudomány számára, mivel önálló, kizárólag csak rá jellemző kutatási témája nincs; megkülönböztető jegyeit a megközelítésmódjából, az egyes gazdasági-társadalmi kérdéseknek a területi aspektusaira történỏ összpontosításából nyeri. Problémáival ugyanakkor foglalkozik a többi társadalomtudomány, létjogosultságát, intézményesültségét annak a gyakorlatnak köszönheti, hogy a társadalomtudósok viszonylag kevés figyelmet fordítanak a területi kérdésekre." (Dusek 2004, 29). Erre az ellentmondásos helyzetre már rögtön a regional science megszületésekor felhívták a figyelmet. Mint Rodwin írja, az isardi regional science szerint, ,a társadalomtudományok nem fektetnek akkora hangsúlyt a térre, amennyit kellene, a földrajztudósok pedig nem elég mély elemzök, ezért szükséges a regional science. De tételezzük fel, hogy a társadalomtudományok sokkal rendszeresebb területi elemzéseket folytatnak és a földrajztudósok sokkal mélyebb elemzőkké válnak. Akkor a regional science nem válna az interdiszciplináris regionális kutatások egy általános elnevezésévé...?" (Rodwin 1959 idézi Isserman 1995, 271).

A továbbiakban hat pontban kívánom tovább árnyalni Probáld Ferenc hivatkozott mondatát.

1) A társadalomföldrajz és a regionális tudomány alapkoncepciói között kategorikus különbség figyelhetö meg: a társadalomföldrajz az egyedi helyek leírásában érdekelt, számára az általánosító szaktudományok és a módszertudományok segédtudomány jellegúek. Ezzel szemben a regionális tudomány módszertudományként vagy általánosító szaktudomány igényével lép fel, számára az egyedi helyekkel kapcsolatos ismeretek a modellek, elméletek és módszerek illusztrációjául szolgálnak. Ez az alapvető különbség (amit Probáld Ferenc nem említ meg) önmagában elegendỏ a regionális tudomány legitimációjához. A társadalomföldrajz és a regionális tudomány közötti viszony például a gazdaságtörténet és közgazdaságtan közötti viszonyhoz, vagy a 
történeti nyelvészet és az elméleti nyelvészet közötti viszonyhoz hasonló. A tudás mindkét formája, az általánosító magyarázatok és az egyedi jelenségek magyarázata egyforma mértékben legitim és a tudomány tárgykörébe tartozó.

2) $\mathrm{Az}$ isardi regionális tudomány elsősorban a német telephelyelmélet amerikai adaptálásaként született, bár céljait tekintve annál több kíván lenni. Azok a kutatások, amelyeket Isard regionális tudomány név alatt végzett (Location and spaceeconomy [1956], Introduction to regional science [1975] stb.), az nem a hagyományos társadalomföldrajz, hanem a közgazdaságtan része volt (illetve lehetett volna) korábban. A regionális tudomány létrejöttét nagyban segítette az, hogy az amerikai közgazdaságtan nem rendelkezett jelentős hagyományokkal a területi kutatások terén. Az angolszász világban az ötvenes években született új földrajzi paradigmának, az elméleti és kvantitatív földrajzi irányzatnak, vagy más néven tértudományi paradigmának, amely a hagyományos társadalomföldrajz mellett párhuzamosan létezett és létezik napjainkban is, kutatási témái és módszerei nagyrészt átfedésben vannak a regionális tudományéval. Ez a földrajzi paradigma Magyarországon nem tudott meggyökeresedni; ha lennének hazai képviselöi, akkor ôk tekinthetnének részben szövetségesként, részben versenytársként a regionális tudományra. Ez a regionális tudománnyal kapcsolatos sajátos szeretem/nem szeretem viszony jellemző az angolszász tértudományi paradigma képviselőinek egy részére is (lásd például Berry 1995).

3) Véleményem szerint a tudáskészlet megkettőződésének lehetôsége nem a társadalomföldrajz-regionális tudomány, hanem a közgazdaságtan (és egyéb általánosító társadalomtudományok) és az általánosító szaktudományként értelmezett regionális tudomány viszonylatában lép fel (a módszertudományi és szaktudományi megközelítésröl lásd Dusek 2004, 21-30). Ez a lehetőség azonban, ismervén a közgazdaságtan elméleteinek térnélküliségét, jelenleg csak elméleti, és nem gyakorlati lehetőség. A közgazdaságtan fóáramát uraló, valóságidegen feltevésekböl kiinduló formalizmus számára térbeli kérdések nem léteznek; ez annyira magától értetődő, hogy a modelleket korlátozó feltételek közül gyakran még a tér hiányának megemlítését is kifelejtik (például a tökéletes verseny modellje kapcsán). A közgazdaságtan fóáramából kiinduló területi kutatások pedig (mint például a „New Economic Geography”), bármennyire dicséretesek is céljukat tekintve, többek között nem képesek elszakadni az egypontgazdaságok hálózatának rendkívül korlátozott térképzetétől, a szállítási költségeket megkérdőjelezhetö módon kezelik, nem nagyon törődnek a területi szintekkel, a formalizálás révén pedig nem jelennek meg bennük az intézményi, kulturális és egyéb jelentős tényezők. A valójában területi kérdésekkel foglalkozó elméletek, mint a vásárlóeröparitás elmélete vagy az optimális valutaövezetek elmélete, még a területi problémák felismeréséig sem jutnak el. A legnagyobb baj azonban az, hogy ezeket az elméleteket gazdaságpolitikai ajánlásokra használják fel (lásd például a maastrichti konvergenciakritériumokat, amely tipikusan térnélküli elméleteken alapul).

4) $\mathrm{Az}$ általánosító szaktudományként értelmezett regionális tudomány paradox módon akkor lenne a legsikeresebb, ha felszámolhatná önmagát (csak mint tudomány, és nem mint kutatási terület vagy szakmai közösség), mert elérte, hogy a 
társadalomtudományoknak inherens részévé vált a területiség kutatása. A regionális tudomány paradox helyzetére utal az is, hogy a területi kérdések kutatásának intézményes önállósulása hozzájárul annak a helyzetnek a fennmaradásához, hogy a térbeliség kutatása a közgazdaságtan fỏáramán kívül maradjon. A közgazdaságtan fóárama és a regionális tudomány közötti kapcsolatok jellemzően aszimmetrikusak, vagyis a fóáramból induló területi kutatások gyakorlatilag többnyire figyelmen kívül hagyják, nem/alig ismerik, vagy félreismerik a regionális tudomány eredményeit (lásd például a New Economic Geography képviselöinek hivatkozási gyakorlatát és terminológiai innovációit). Ez nem a regionális tudomány, hanem a fỏáram képviselőinek felróható intézményes probléma. A módszertudományként értelmezett regionális tudományt ugyanakkor semmi sem veszélyezteti, mint ahogyan a véletlen tömegjelenségekkel foglalkozó valószínüségszámítás sem szünne meg, ha minden szaktudomány mủvelöje egyben statisztikus is lenne.

5) A félreértések elkerülése érdekében célszerü megkülönböztetni a regionális tudomány nomotetikus igényư alapkoncepcióját és nemzetközi, angol nyelvú gyakorlatát, valamint a regionális tudomány hazai gyakorlatát. A nemzetközi gyakorlatban, a regionális tudományi konferenciákon és a regionális tudomány szakfolyóirataiban, nem nagyon lehet találkozni a hagyományos társadalomföldrajz tárgykörébe tartozó kutatásokkal. A régióleírások hiánya képezi az egyik leggyakoribb, ám indokolatlan kritika tárgyát az isardi regionális tudományra vonatkozóan a hagyományos társadalomföldrajz oldaláról. Ezzel szemben a regionális tudomány hazai gyakorlata részben elválik a nemzetközi gyakorlattól (lásd Probáld Ferenc nyolcadik lábjegyzetét a „Kárpát-medence régiói” sorozatról). Hazánkban nagyobb arányban jelennek meg területfejlesztési kérdések és a regionális földrajz tárgykörébe tartozó régióleírások. Így Magyarországon - ellentétben a nemzetközi gyakorlattal - a regionális tudomány kutatási témái részben átfedésben lehetnek a hagyományos társadalomfơldrajz kutatási témáival. Ez vezet ahhoz a furcsa (és véleményem szerint nem kedvezö) helyzethez, hogy hazánkban a regionális tudomány tárgyaként olykor a konkrét, különböző szintủ magyarországi közigazgatási egységek leírását teszik meg, amely hagyományosan a társadalomföldrajz feladata. Ennek a pontnak a második felében csatlakoznék Probáld Ferenc idézett mondatához, míg a korábbi négy és fél pont a társadalomföldrajz és regionális tudomány alapvetően eltérő feladatkörei és a regionális tudomány szükségessége mellett érvelt.

6) A földrajztudomány közoktatásbeli szerepének, tekintélyének növelése a földrajztudomány és a regionális tudomány közös érdeke. A fơldrajzoktatás képes általánosságban is növelni a társadalom területi kérdések iránti fogékonyságát, és megalapozni azt, hogy a felsőoktatásba a területi kérdések iránt érdeklődő és fogékony, térképet olvasni képes hallgatók kerüljenek. A területi kérdések oktatásban betöltött szerepének növelése a tisztán regionális tematikájú tárgyak mellett a hagyományos tantárgyakon belül is lehetséges és kívánatos (Dusek 2006). Ennek tudatosítása a regionális tudomány múvelőinek a feladata. A regionális tudományt önmagában a területfejlesztés igényei is legitimálják, de interdiszciplináris presztízst nem ettől, 
hanem elsösorban (a területfejlesztést is megalapozni képes) elméleti, módszertani jellegü kutatásoktól remélhet. Ezt a célt jól szolgálják a regionális tudományi témájú elméleti monográfiák, mint például Nemes Nagy József A tér a társadalomkutatásban vagy Lengyel Imre és Rechnitzer János Regionális gazdaságtan címü könyvei. A Tér és Társadalomban megjelenỏ módszertani tanulmányok, valamint az ilyen jellegü elöadásoknak teret adó tudományos konferenciák (mint a 2006 novemberében az ELTE-n megrendezett Regionális modellek címü konferencia) szintén rendkívül hasznosak a külső presztízs növelése szempontjából.

\section{Jegyzet}

${ }^{1}$ A tanulmány a Bolyai János Kutatási Ösztöndíj támogatásával készült.

\section{Irodalom}

Berry, B.J.L. (1995) Whither regional science? - International Regional Science Review. 3. 297-306. o. Dusek T. (2004) A területi elemzések alapjai. Regionális Tudományi Tanulmányok 10. ELTE, Budapest. Dusek T. (2006) Területi statisztika az oktatásban. - Széchenyi István Egyetem GTI Tudományos Füzetek. 10. Universitas-Györ Kht., Györ. 184 198. o.

Isard, W. (1956) Location and space-economy. MIT Press, Cambridge.

Isard, W. (1975) Introduction to regional science. Prentice-Hall, New Jersey.

Isserman, A.M. (1995) The history, status, and future of regional science: an American perspective. International Regional Science Review. 3. 249-296. o.

Lengyel I.-Rechnitzer J. (2004) Regionális gazdaságtan. Dialog Campus, Budapest-Pécs.

Nemes Nagy J. (1998) A tér a társadalomkutatásban (Bevezetés a regionális tudományba) Hilscher Rezső Szociálpolitikai Egyesület, Budapest.

Probáld F. (2007) Társadalomföldrajz és regionális tudomány, - Tér és Társadalom. 1. 21-33. o. 